\title{
The use of medicinal plants to prevent COVID-19 in Nepal
}

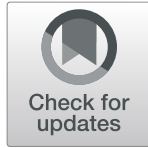

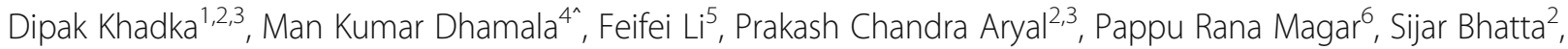
Manju Shree Thakur ${ }^{2}$, Anup Basnet ${ }^{2}$, Dafang Cui ${ }^{1 *}$ and Shi Shi ${ }^{1,7^{*}}$ (i)

\begin{abstract}
Background: Medicinal plants are the fundamental unit of traditional medicine system in Nepal. Nepalese people are rich in traditional medicine especially in folk medicine (ethnomedicine), and this system is gaining much attention after 1995. The use of medicinal plants has increased during the COVID-19 pandemic as a private behavior (not under the control of government). A lot of misinterpretations of the use of medicinal plants to treat or prevent COVID-19 have been spreading throughout Nepal which need to be managed proactively. In this context, a research was needed to document medicinal plants used, their priority of use in society, their cultivation status, and the source of information people follow to use them. This study aimed to document the present status of medicinal plant use and make important suggestion to the concerned authorities.

Methods: This study used a web-based survey to collect primary data related to medicinal plants used during COVID-19. A total of 774 respondents took part in the survey. The study calculated the relative frequencies of citation (RFC) for the recorded medicinal plants. The relationship between plants recorded and different covariates (age, gender education, occupation, living place, and treatment methods) was assessed using Kruskal-Wallis test and Wilcoxon test. The relationship between the information sources people follow and the respondent characteristics was assessed using chi-square test.
\end{abstract}

Results: The study found that the use of medicinal plants has increased during COVID-19 and most of the respondents recommended medicinal plants to prevent COVID-19. This study recorded a total of 60 plants belonging to 36 families. The leaves of the plants were the most frequently used. The Zingiber officinale was the most cited species with the frequency of citation 0.398 . Most of the people (45.61\%) were getting medicinal plants from their home garden. The medicinal plants recorded were significantly associated with the education level, location of home, primary treatment mode, gender, and age class. The information source of plants was significantly associated with the education, gender, method of treatment, occupation, living with family, and location of home during the lockdown caused by COVID-19.

Conclusions: People were using more medicinal plants during COVID-19 claiming that they can prevent or cure COVID-19. This should be taken seriously by concerned authorities. The authorities should test the validity of these medicinal plants and control the flow of false information spread through research and awareness programs.

Keywords: Corona, COVID-19, Knowledge, Medicinal plants, Pandemic, People, Prevent

\footnotetext{
*Correspondence: cuidf@scau.edu.cn; shis@scau.edu.cn

"Man Kumar Dhamala is deceased. We would like to dedicate this paper in the

memory of Dr. Man Kumar Dhamala who died on November 5, 2020.

'Guangdong Key Laboratory for Innovative Development and Utilization of

Forest Plant Germplasm, College of Forestry and Landscape Architecture,

South China Agricultural University, Guangzhou, China

Full list of author information is available at the end of the article
}

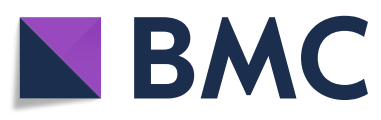

(ㄷ) The Author(s). 2021 Open Access This article is licensed under a Creative Commons Attribution 4.0 International License, which permits use, sharing, adaptation, distribution and reproduction in any medium or format, as long as you give appropriate credit to the original author(s) and the source, provide a link to the Creative Commons licence, and indicate if changes were made. The images or other third party material in this article are included in the article's Creative Commons licence, unless indicated otherwise in a credit line to the material. If material is not included in the article's Creative Commons licence and your intended use is not permitted by statutory regulation or exceeds the permitted use, you will need to obtain permission directly from the copyright holder. To view a copy of this licence, visit http://creativecommons.org/licenses/by/4.0/ The Creative Commons Public Domain Dedication waiver (http://creativecommons.org/publicdomain/zero/1.0/) applies to the data made available in this article, unless otherwise stated in a credit line to the data. 


\section{Background}

The new coronavirus disease (COVID-19) pandemic has caused global socioeconomic disturbances with a worrisome number of deaths and health issues, and the world has been struggling to find medicine to treat and prevent COVID-19 [1]. A number of combinations and trials have been done, but so far, they have not produced promising results [2-4]. The different types of misinformation related to COVID-19 have been spreading throughout the world through social media [5], including use of medicinal plant products to prevent or cure COVID-19. Due to this situation, ethnobiologists should collaborate with local people and document the medicinal plants used with caution to stop the inaccurate sharing of information [6].

There is a strong inter-relationship between people and plants according to needs [7-10]. People are dependent on plants for different purposes such as for food, medicine, and houses [11-13]. Plant species have always been a fundamental source for the discovery of drugs [14]. People had used medicinal plants to fight against pandemics in the past [15-17], and dependency of people on medicinal plants might have increased in these days around the world as medicinal plants can be an alternative option to prevent COVID-19 [18].

Different researchers have suggested herbal medicine as a potential option to cure or prevent COVID-19 [19, 20]. Countries like China and India are integrating their use with western medicine to boost the immunity power of COVID-19 patients [21, 22]. In China, traditional medicine showed encouraging results in improving symptom management and reducing the deterioration, mortality, and recurrence rates [23]. On the other hand, the World Health Organization (WHO) (2020) claims medicinal plants might be good for the health and in supporting the immune system, but not in preventing or curing COVID-19. The WHO Africa (2020) claims unscientific products to treat COVID-19 can be unsafe for people, as they may abandon self-hygienic practices, may increase self-medication, and may be a risk to patient safety.

Lifestyle, diet, age, sex, medicinal conditions, and environmental factors have been playing an important role in the personal fate towards the severity of COVID-19 [24]. The source of information, such as social media, plays an important role to combat pandemics [25, 26]. People receive information regarding COVID-19 and other diseases from different sources including the social media, local people, national health authorities, and the WHO, based on respondent characteristics such as age and gender as well as occupation, state of their living, and primary mode of disease treatment method [27].

In Nepal, the medicinal plants are often used in the traditional medicine system, which includes Scholarly medical system (The Ayurveda, homeopathy, the Unani, and the Tibetan medicine), Folk medicine (ethnomedicine, community medicine, household medicine, and any other forms of local medicines), and Shamanistic (Dhami-jhankri, Jharphuke, Pundit-Lama-Pujari-Gurau, and Jyotish). Among them, folk medicine system is using more medicinal plants in Nepal [28]. The first scientific research published in ethnobotany is dated back to 1955 [29]. More than $80 \%$ of the people in Nepal have been using traditional medicine such as medicinal plants [30, 31]. Medicinal plants are the primary source of healthcare for the people in Nepal and are an integral part of their culture [32, 33]. Most of the people in Nepal have been using medicinal plants as the alternative to allopathic or western medicine [34].

It has also been playing an important role in increasing the economic level of people [35] as Nepal exports medicinal plants to different countries in the world [36]. The elder people living in rural areas have more knowledge of traditional medicine [37].

In Nepal, COVID-19 cases are increasing daily but the health care system is fragile and has a lack of infrastructure [38]. In this context, home remedies, like the use of medicinal plants supported by the relevant authorities, can serve as an alternative option to combat COVID-19. The Nepal government has also valued medicinal plants as an immunity power booster used with prescriptions [39]. But, there a considerable amount of false information spread in Nepal regarding the use of medicinal plants and people are randomly using plants which can go against the traditional methodology and make it difficult to combat COVID-19. The present study has attempted to reveal the status of medicinal plant use in Nepal during COVID-19. Specifically, this study is aimed to address the following objectives: (1) document the status and source of medicinal plants used to prevent COVID-19, (2) know the relationship between the number of plants reported and covariates, and (3) know the relationship between information sources respondents follow and respondent characteristics.

\section{Methods \\ Methods of data collection}

A set of questionnaire forms were prepared by Google Form developer. The Google Form was initially tested to validate and understand the response rate from respondents. We followed the code of ethics of the International Society of Ethnobiology [40]. We wrote a consent message to all the people we reached with the form and also placed clearly written consent message at the top of the form. Additionally, we asked a consent question at the beginning of the form for written consent from each respondent. The Google Form was circulated through social media (such as Facebook) and emails in our friend circles asking them to circulate the form with consent message at first as much as possible 
and inform us whether the form has been sent to others. From our friend circles' help and our efforts, we reached a total of 998 people throughout the online survey in June 09,2020 , to July 18,2020 , in which a total of 774 (77.55\%) people filled the form in different parts of Nepal and provided information about the different variables (Table 1) used for the study.

\section{Sample population}

A total of 774 respondents participated in the survey, of whom $407(52.58 \%)$ were from the urban area and 367 $(47.42 \%)$ were from the rural area. The age of the respondents varied from 16 to 76 years. Among them, 65.51\% were below 30 years of age; all of the respondents were literate, and most of them (69.5\%) had attended University. There were more male respondents (60.85\%) than female (Table 2).

\section{Data analysis}

The status of medicinal plants used during COVID-19 (increase, decrease, same, and never used) and recommendation of medicinal plants (strong, moderate, low, and never) was calculated and shown in the bar graph using Microsoft Excel 2013.

The medicinal plants recorded were tabulated in the table with respective scientific, local, and English names with their family and parts (root, stem, leaves, rhizome, roots) used. The scientific names from local name identification followed the Dictionary of Nepalese plant nam e[41] and ethnomedicine study from Nepal [42], and the family assignation in this paper followed the TROPICOS [43]. Finally, we reaffirmed plant species by taxonomic experts from Tribhuvan University Nepal and collected herbarium specimens were deposited in the National Herbarium and Plant Laboratories (KATH) Godawari, Lalitpur Nepal, and specimen codes were presented in a table for each species. For all the species, frequency of citation (FC) and relative frequency of citation (RFC) were calculated following Tardio and Pardo-de-Santayana (2008) [44].

$$
R F C=\frac{F C}{N}
$$

where $\mathrm{FC}=$ number of respondents who mentioned the

Table 1 Description of the variables used in this study

\begin{tabular}{|c|c|c|c|c|}
\hline Variable & Type & Symbol & Categories & Remarks/ Details \\
\hline Plant number & Numeric & Plants & NA & Number of plant species used \\
\hline Education & Ordinal & Education & Primary, secondary, university & Formal education of respondents \\
\hline Occupation & Nominal & Occupation & $\begin{array}{l}\text { Agriculture, business, job, jobless, } \\
\text { wage earner, remittance }\end{array}$ & $\begin{array}{l}\text { The main source of livelihood of the } \\
\text { respondents }\end{array}$ \\
\hline Age & Ordinal & Age & $\begin{array}{l}>20 \\
20-29 \\
30-39 \\
40-49 \\
50-59 \\
60-69 \\
70-79\end{array}$ & Age of the respondents \\
\hline Gender & Nominal & Sex & $\begin{array}{l}\text { Male (M) } \\
\text { Female (F) }\end{array}$ & Gender of the respondents \\
\hline Primary treatment mode & Nominal & Primary treatment mode & Allopathy, Ayurvedic, homeopathy & Mode of treatment people normally follow \\
\hline Source of information & Nominal & Source of information & $\begin{array}{l}\text { WHO, national health authorities, } \\
\text { social media, local community }\end{array}$ & $\begin{array}{l}\text { Source of information people follow to use } \\
\text { medicinal plant }\end{array}$ \\
\hline Medicinal plant use & Ordinal & Medicinal plant use status & $\begin{array}{l}\text { Increase, decrease, same, } \\
\text { never used }\end{array}$ & $\begin{array}{l}\text { The medicinal plant use status during } \\
\text { COVID-19 compared to before COVID-19 }\end{array}$ \\
\hline $\begin{array}{l}\text { Recommendation of } \\
\text { medicinal plant }\end{array}$ & Ordinal & Recommendation & Strong, moderate, low, never & $\begin{array}{l}\text { Respondents' recommendation levels } \\
\text { were recorded }\end{array}$ \\
\hline $\begin{array}{l}\text { Living conditions } \\
\text { during lockdown }\end{array}$ & Nominal & Living conditions & Urban, rural & $\begin{array}{l}\text { The place of living during lockdown was } \\
\text { recorded }\end{array}$ \\
\hline Living with family & Nominal & Living with family & $\begin{array}{l}\text { Yes } \\
\text { No }\end{array}$ & $\begin{array}{l}\text { Respondents living with family or not are } \\
\text { recorded }\end{array}$ \\
\hline Plant growing conditions & Ordinal & $\begin{array}{l}\text { Medicinal plant growing } \\
\text { condition }\end{array}$ & Less, same, more, started, never & $\begin{array}{l}\text { Plants' growing conditions during } \\
\text { COVID-19 pandemic }\end{array}$ \\
\hline $\begin{array}{l}\text { Knowledge about } \\
\text { medicinal plant }\end{array}$ & Ordinal & $\begin{array}{l}\text { Knowledge of medicinal } \\
\text { plant }\end{array}$ & Increase, decrease, same, confused & $\begin{array}{l}\text { The respondents' knowledge level on the } \\
\text { use of medicinal plant }\end{array}$ \\
\hline Habit analysis & Nominal & Habit & Herb, shrub, climber, tree & $\begin{array}{l}\text { Types of plant mentioned by the } \\
\text { respondents }\end{array}$ \\
\hline
\end{tabular}


Table 2 Demographic profile of respondents

\begin{tabular}{|c|c|c|c|}
\hline Demographic parameter & Description & Total respondents $(n=774)$ & Frequency (\%) \\
\hline \multirow[t]{7}{*}{ Age } & $>20$ & 31 & 4.01 \\
\hline & $20-29$ & 476 & 61.5 \\
\hline & $30-39$ & 121 & 15.63 \\
\hline & $40-49$ & 64 & 8.27 \\
\hline & $50-59$ & 50 & 6.46 \\
\hline & $60-69$ & 23 & 2.98 \\
\hline & $70-79$ & 9 & 1.16 \\
\hline \multirow[t]{2}{*}{ Sex } & Male & 471 & 60.85 \\
\hline & Female & 303 & 39.15 \\
\hline \multirow[t]{3}{*}{ Education } & Primary & 36 & 4.65 \\
\hline & Secondary & 200 & 25.84 \\
\hline & University & 538 & 69.5 \\
\hline
\end{tabular}

use of species and $N=$ total number of respondents took part in a survey.

The results of the RFC and the top 10 medicinal plants used are presented in the radar diagram using Microsoft Excel 2013.

The Shapiro test, Kruskal-Wallis test, Wilcoxon test, chi-square test, and related diagrams were drawn using $R$ [45]. The Shapiro test was performed to test the normality of the data. As the data of plant number was not normally distributed, the Kruskal-Wallis test was performed to test the relationship between several plants with an occupation, education level, primary treatment mode, and age class. The Wilcoxon test was performed to see the differences in number of plants reported with gender and place of living during COVID-19 pandemic.
The relationship between information sources and respondent characteristics was shown in the graph and statistically analyzed using the chi-square test.

\section{Results}

Status of medicinal plant use

Out of 774 respondents, 323 (42\%) respondents agreed that the use of the medicinal plant has increased during COVID-19, whereas 313 (40.44\%) agreed the use of medicinal plants during COVID-19 is the same as that of normal condition (Fig. 1).

Most of the respondents, 349 (45.09\%), believed that information/knowledge of medicinal plants has increased during COVID-19, 333 (43.02\%) believed it is the same as usual, and 93 (11.89\%) considered that they are confused about the use of medicinal plants (Fig. 2).

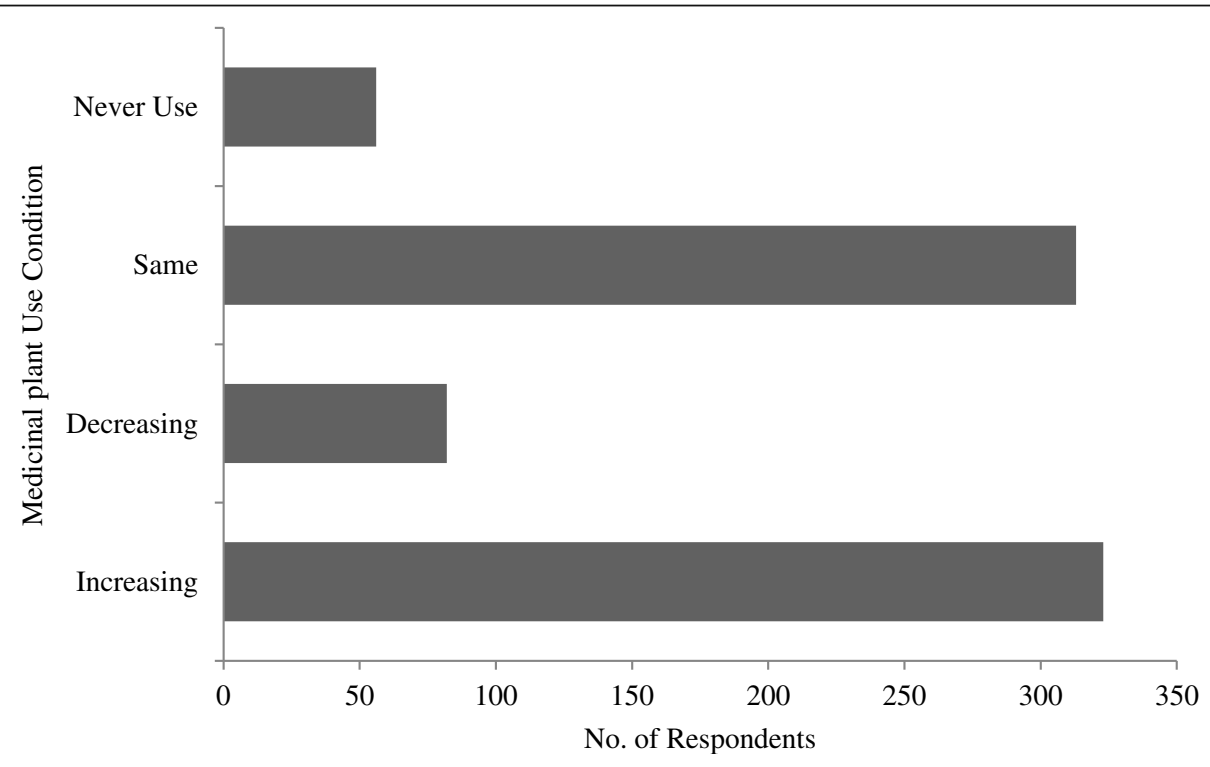

Fig. 1 Trend of medicinal plant use during COVID-19 


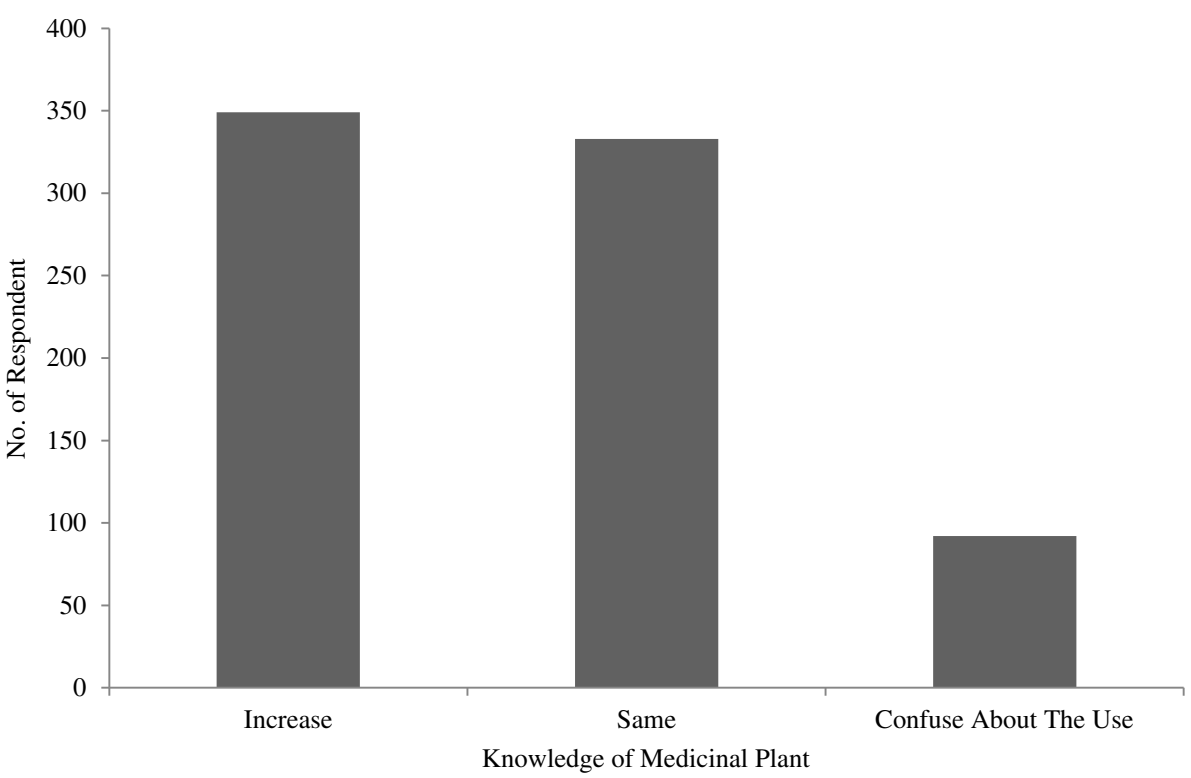

Fig. 2 The knowledge level of people on the use of medicinal plants during COVID-19

A total of $670(86.5 \%)$ of the respondents had recommended medicinal plants to prevent COVID-19, whereas 104 (13.4\%) had not recommended. Most of them had made a moderate recommendation (Fig. 3).

\section{Medicinal plants recorded}

A total of 60 species of medicinal plants from 36 families and 54 genera were documented as being perceived. Among them, the most common families were Apiaceae (6 species), Zingiberaceae (4 species), Amaryllidaceae (4 species) and Lamiaceae (4species). And most common genus were Allium (3 species), Terminalia (2 species),
Mentha (2 species), Cinnamomum (2 species), and Syzygium. Likewise, the most perceived species was Zingiber officinale (39.79\%) followed by Curcuma angustifolia (34.11\%). The habit analysis showed that the medicinal plants belonging to herb, shrub, climber, and tree species were $56.67 \%, 11.67 \%, 6.67 \%$, and $25 \%$ respectively (Table 3$)$. Leaves $(33.68 \%)$ were the most predominantly used parts, followed by seeds (23.33\%), fruits (21.67\%), roots $(13.33 \%)$, rhizomes $(11.67 \%)$, whole plant $(8.33 \%)$, bark (6.67\%) stem (1.67\%), and bulb (1.67\%) (Fig. 4). The most commonly used method of preparations was to grind the parts, boil with hot water or milk, and drink.

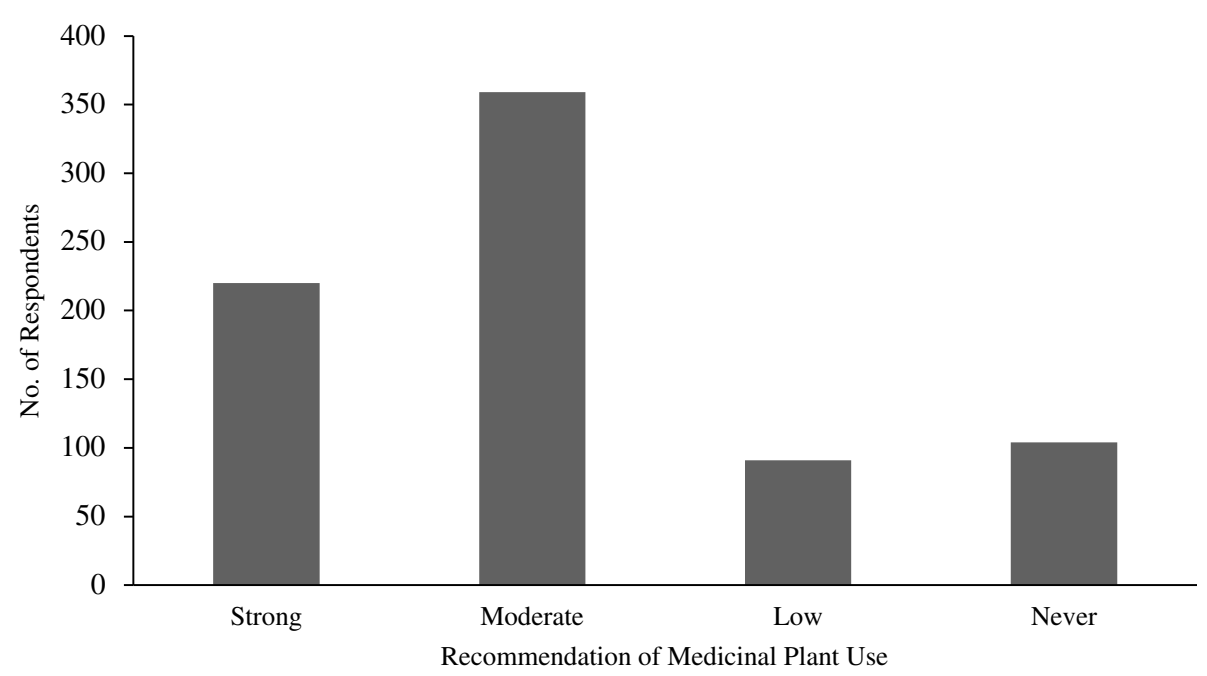

Fig. 3 Recommendation of a medicinal plant to prevent and cure COVID-19 


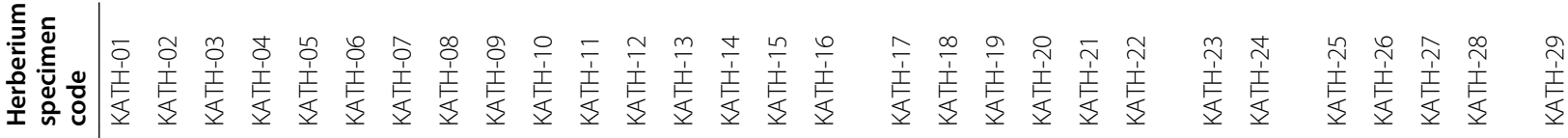
u u

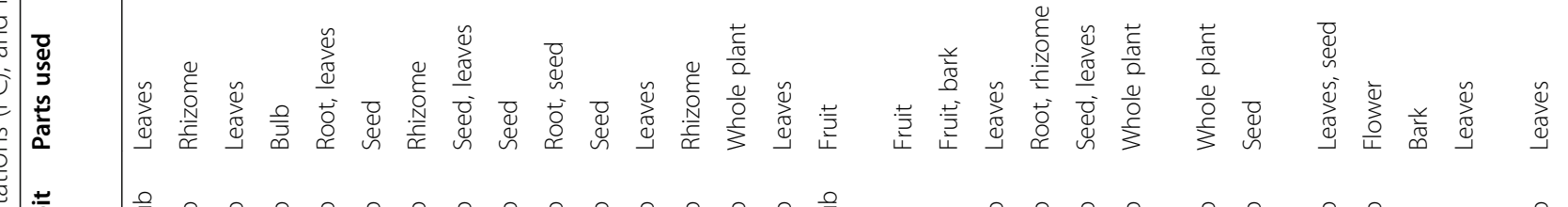

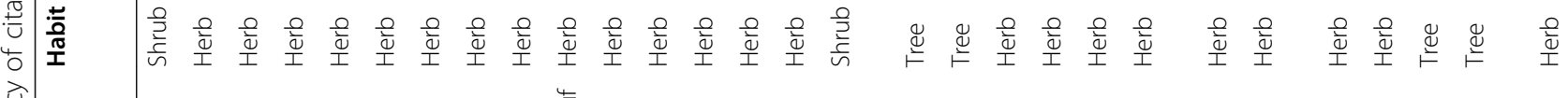

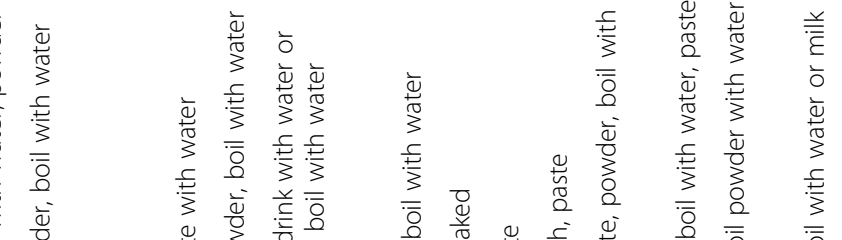

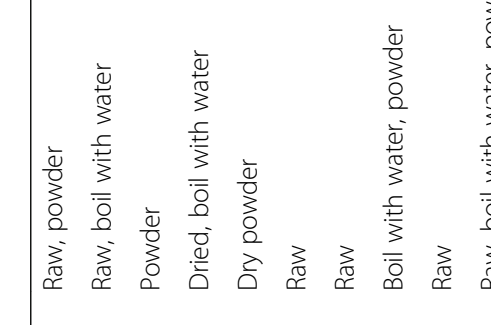

㐫

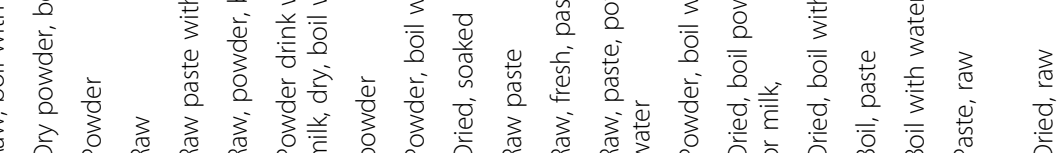

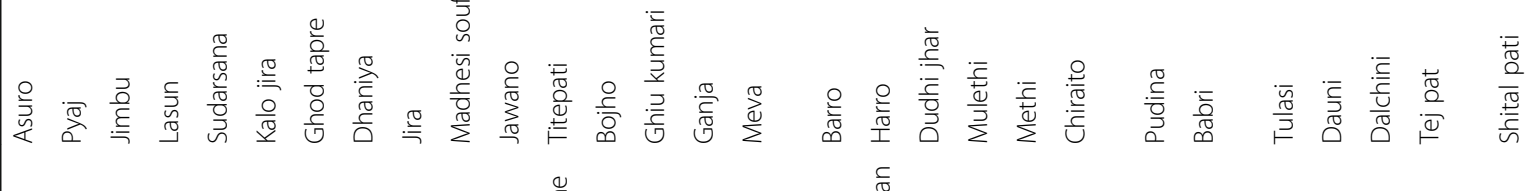

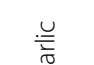

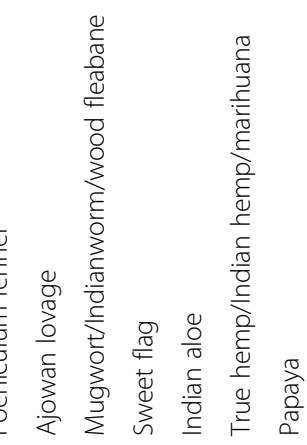<smiles>[B]C</smiles> 


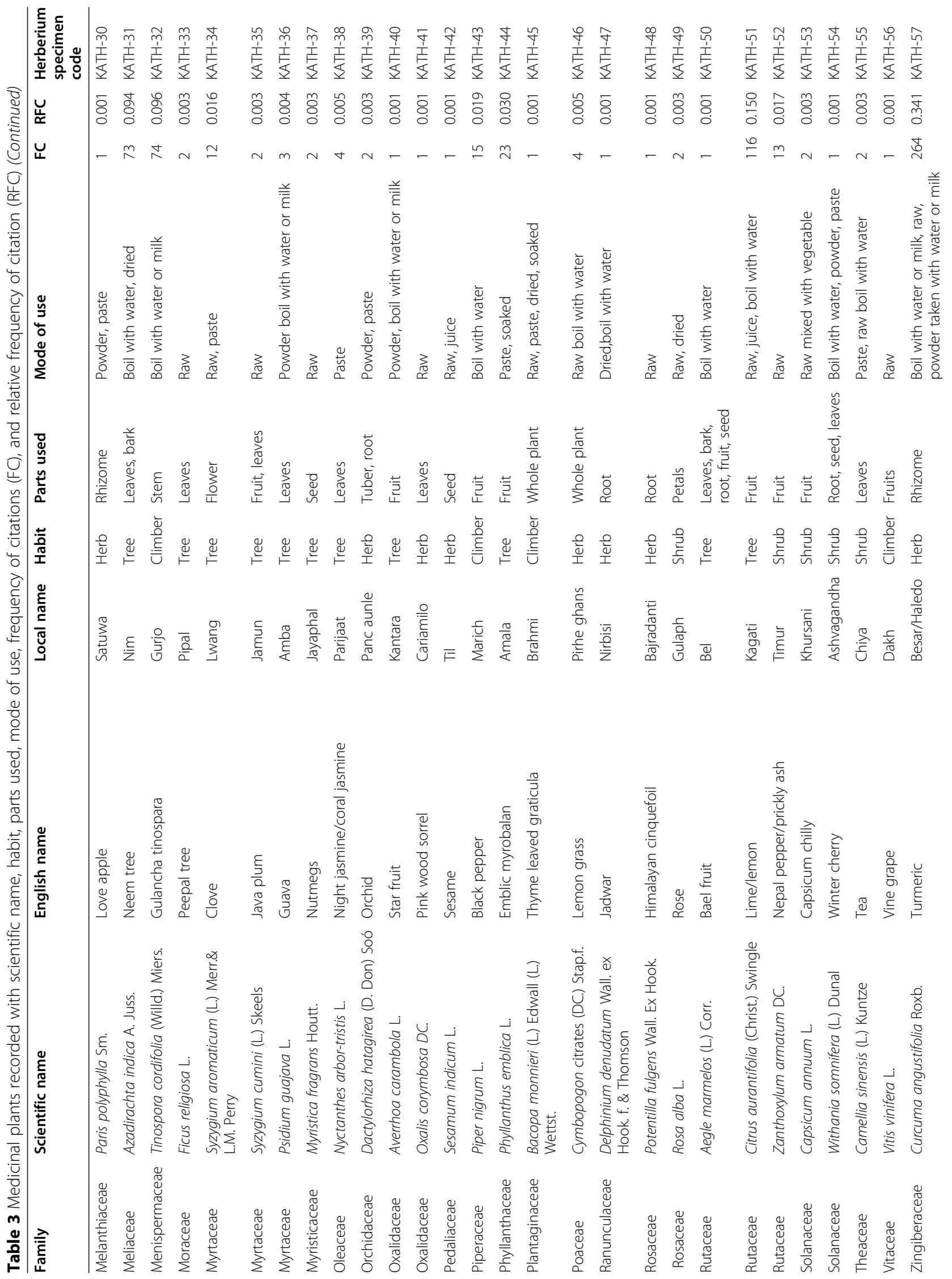




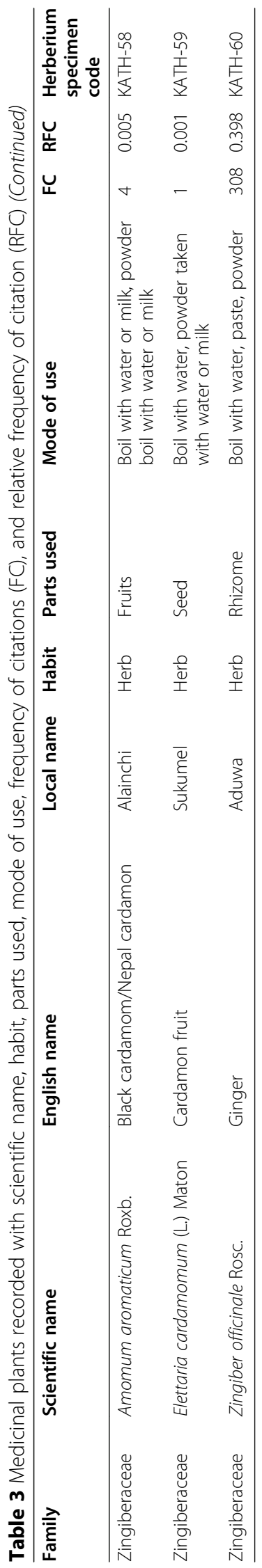




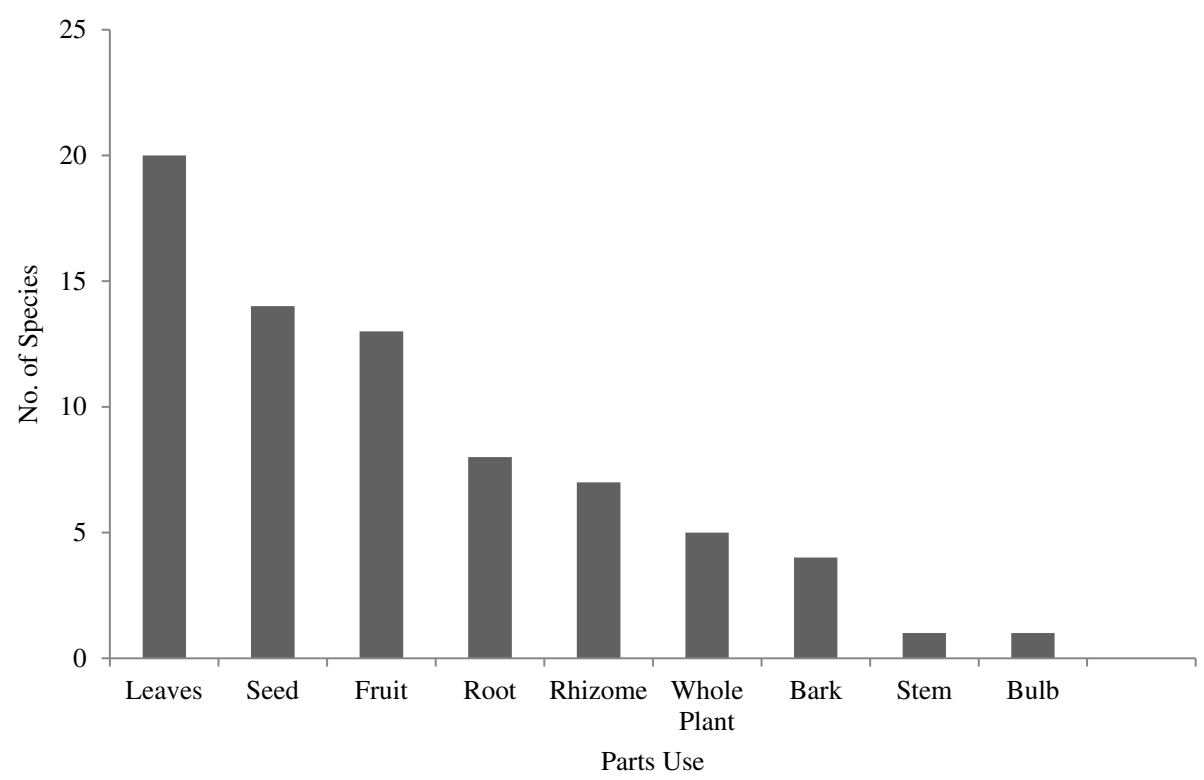

Fig. 4 Parts of plants used for medicinal purpose to prevent COVID-19

\section{Relative frequency of citation}

The relative frequencies of citations ranged from 0.001 to 0.398 and for ten most cited species value ranged from 0.03 to 0.398 . The most cited species was Zingiber officinale (308 times cited and frequency of citation was 0.398) followed by Curcuma angustifolia (264 times cited and frequency of citation was 0.341) (Fig. 5).

\section{Source and cultivating conditions of medicinal plants}

The respondents had mentioned that they were getting medicinal plants from home gardens (45.61\%), markets
(32.03\%), and jungles (10.73\%), and the remaining respondents were getting medicinal plants from all of the above three sources. Most of the respondents were also cultivating (47\%) more medicinal plants during COVID19 than before, and few have just started (3\%) (Fig. 6).

\section{Number of plants reported and covariates}

The number of reported plants used by individual respondents ranged from 0 to 12 (Fig. 7). In the occupational category, people who were engaged in agriculture and those with jobs used comparatively more medicinal

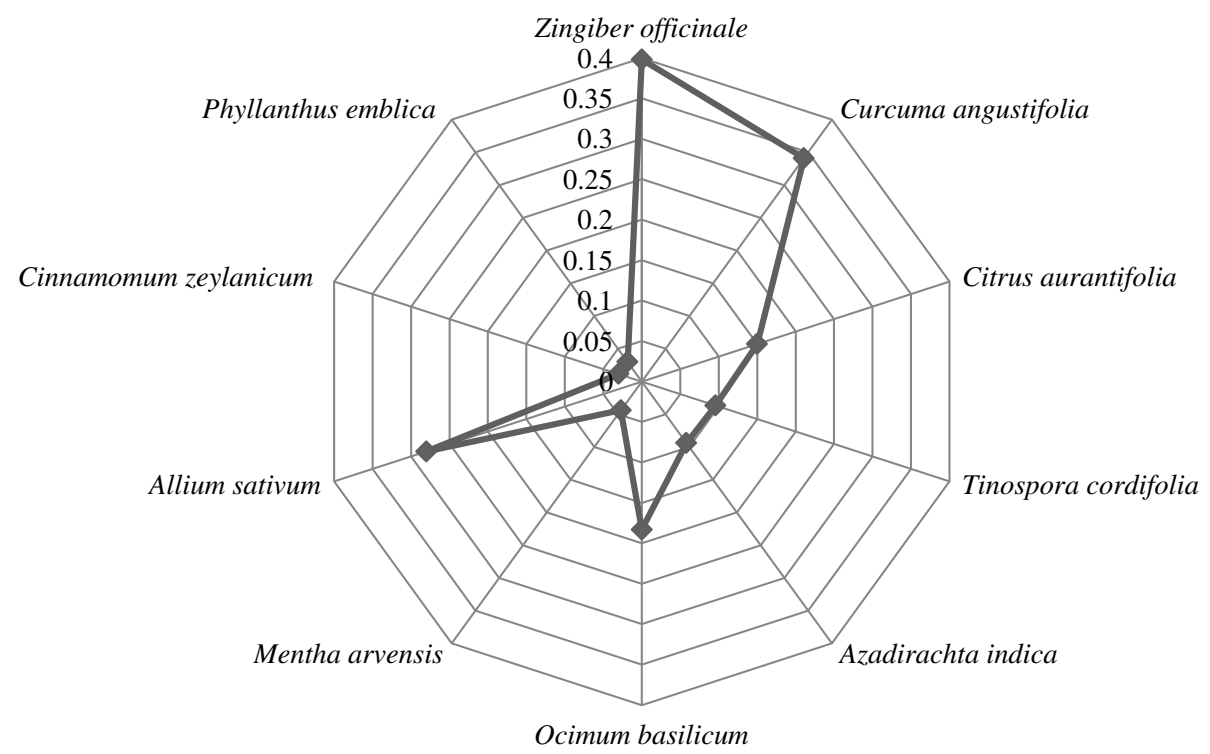

Fig. 5 List of top ten ranked plant species reported by respondents shown the frequency of citation 


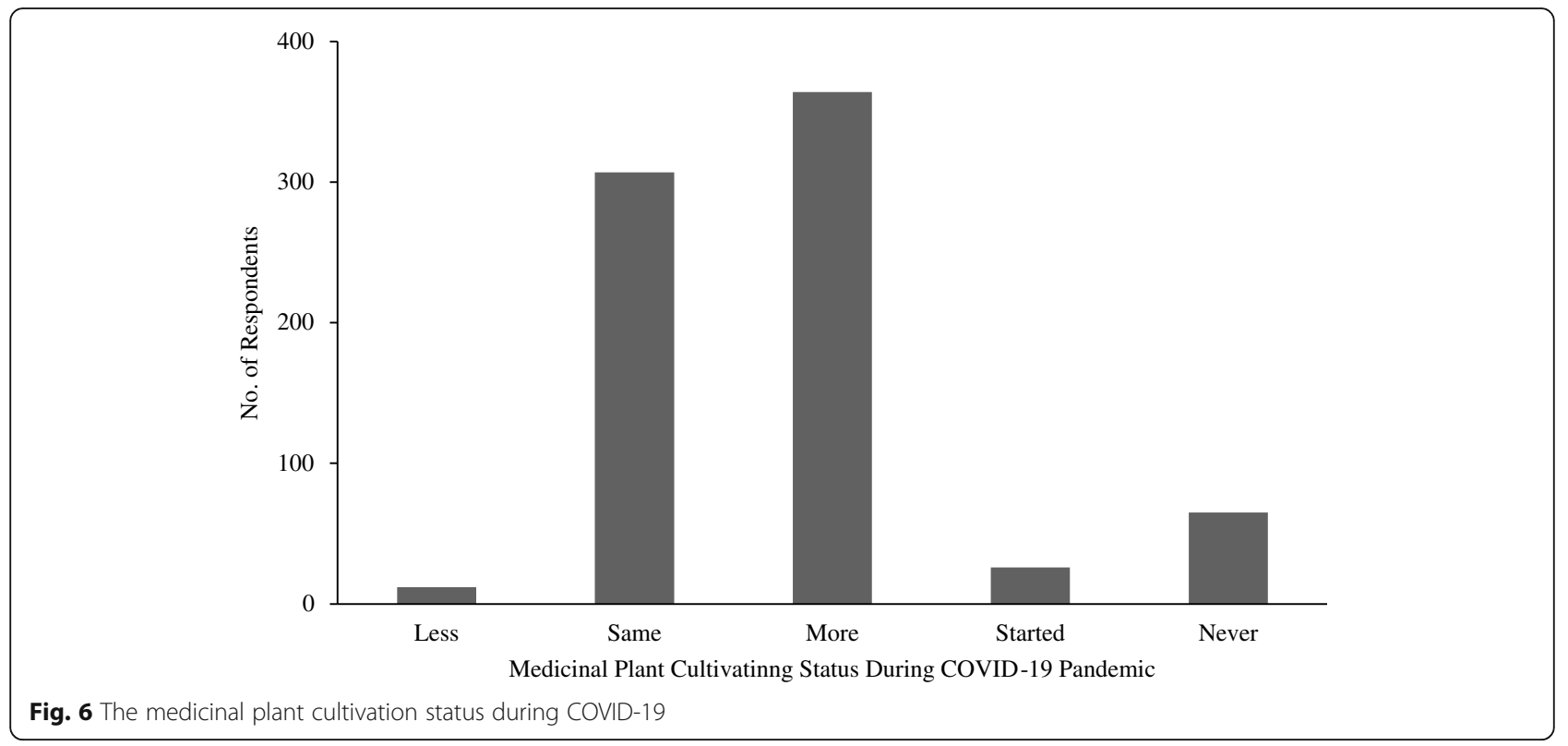

plants than others, but the difference was not significant (Kruskal-Wallis, $\chi^{2}=7.921$, df $=5, p=0.1606$ ). The people with university-level education were using more plant species compared to people with secondary-level and primary-level education, and the differences were statistically significant ( Kruskal-Wallis, $\chi^{2}=50.736$, df $=$ $2, p=<0.0001)$. The people living in the city were using more plants than people living in the village, which was statistically significant $(W=85818, p=$ 0.0002). The people whose primary method of treatment was allopathic were using a statistically significant low number of plants (Kruskal-Wallis, $\chi^{2}=32.524, \mathrm{df}=3, p$ $=0.0001)$ compared to the respondents whose primary methods of treatment were Ayurvedic and homeopathic. The female respondents were using more plants than males; the difference in the use of plants by males and

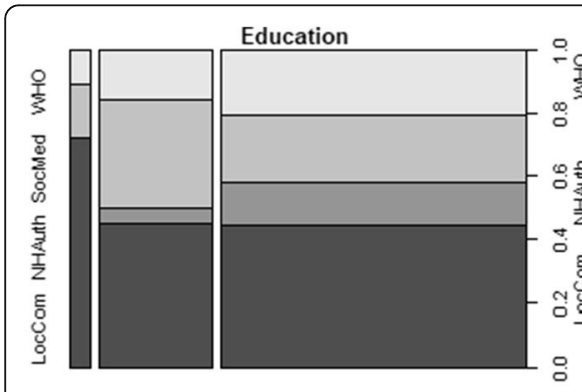

Primary

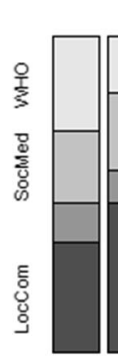

No
University

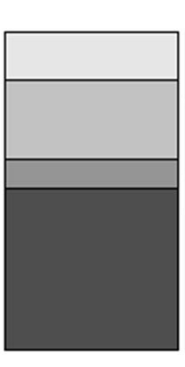

$\mathrm{F}$

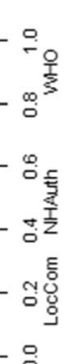

Yes

Allopathy

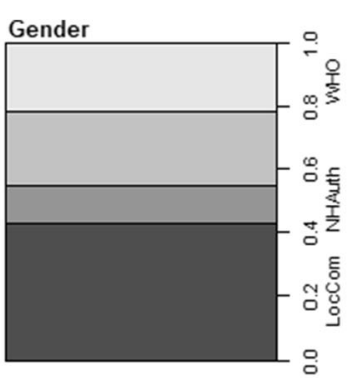

M

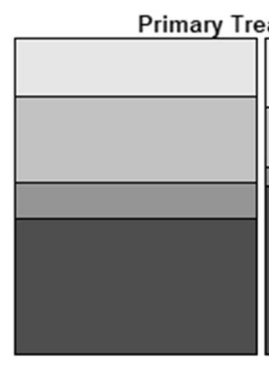

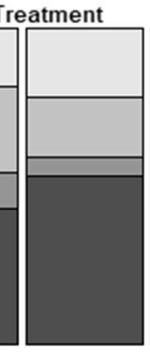

Ayurvedic

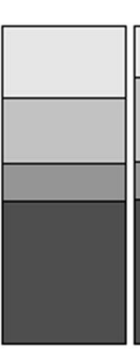

Agriculture Business

Living in Lockdown

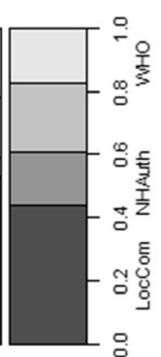

:

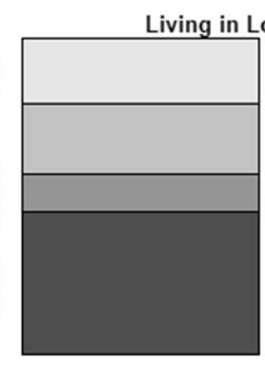

City

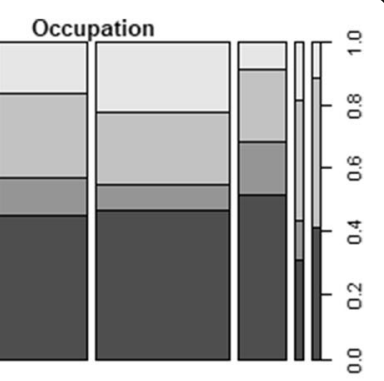

Job Jobless

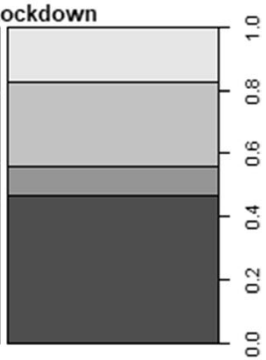

Village

Fig. 7 Graphical representation of plant use as a preventive method against COVID-19 by respondents 
females was statistically significant $(W=77489, p=$ $0.03864)$. Age group of $20-29$ and below $(<20)$ reported more number of species being used. The number of medicinal plant species reported was statistically significantly different among the age groups (Kruskal-Wallis, $X^{2}=25.484, \mathrm{df}=6, p=0.0003$ ).

\section{Information sources}

People are using different sources to prevent COVID-19, such as social media like Facebook Twitter, official information from the World Health Organization, the national health authorities, and local communities (Fig. 8). The information adopted from social media is risky but in significant proportion, more than $25 \%$ of secondary education respondents and female respondents are using social media information, and there was a statistically significant relationship between information source and gender $\left(\chi^{2}=8.0304, p=0.0459\right)$. The relationship between information source and education was statistically significant $\left(\chi^{2}=34.714, p=0.0005\right)$. The jobless people were following the local community for obtaining information (more than 50\%), and the relationship between the source of information and occupation was marginally significant $\left(x^{2}=23.863, p=0.0699\right)$. The people living with their families were depending more on local communities and social media for plant use information (more than $50 \%$ and $25 \%$ respectively), and the relationship between the source of information and living with the family was statistically significant $\left(\chi^{2}=\right.$ 7.9621, $p=0.0445$ ). The people who using Ayurvedic as the primary treatment were mainly following information provided by the communities (more than $50 \%$ ), and there was a statistically significant association between the information source and the primary treatment method $\left(\chi^{2}=17.406, p=0.0095\right)$. The people living in the city and village during the lockdown of COVID-19 both followed similar sources of information, and there is no significant association between source of information and people living in lockdown $\left(\chi^{2}=4.6375, p=\right.$ 0.2054).

\section{Discussion}

\section{Status and sources of medicinal plant}

Medicinal plants have attracted the attention of several stakeholders around the world [46]. They have chemical diversity and can play a significant role in new drug development [47]. In this study, the majority of

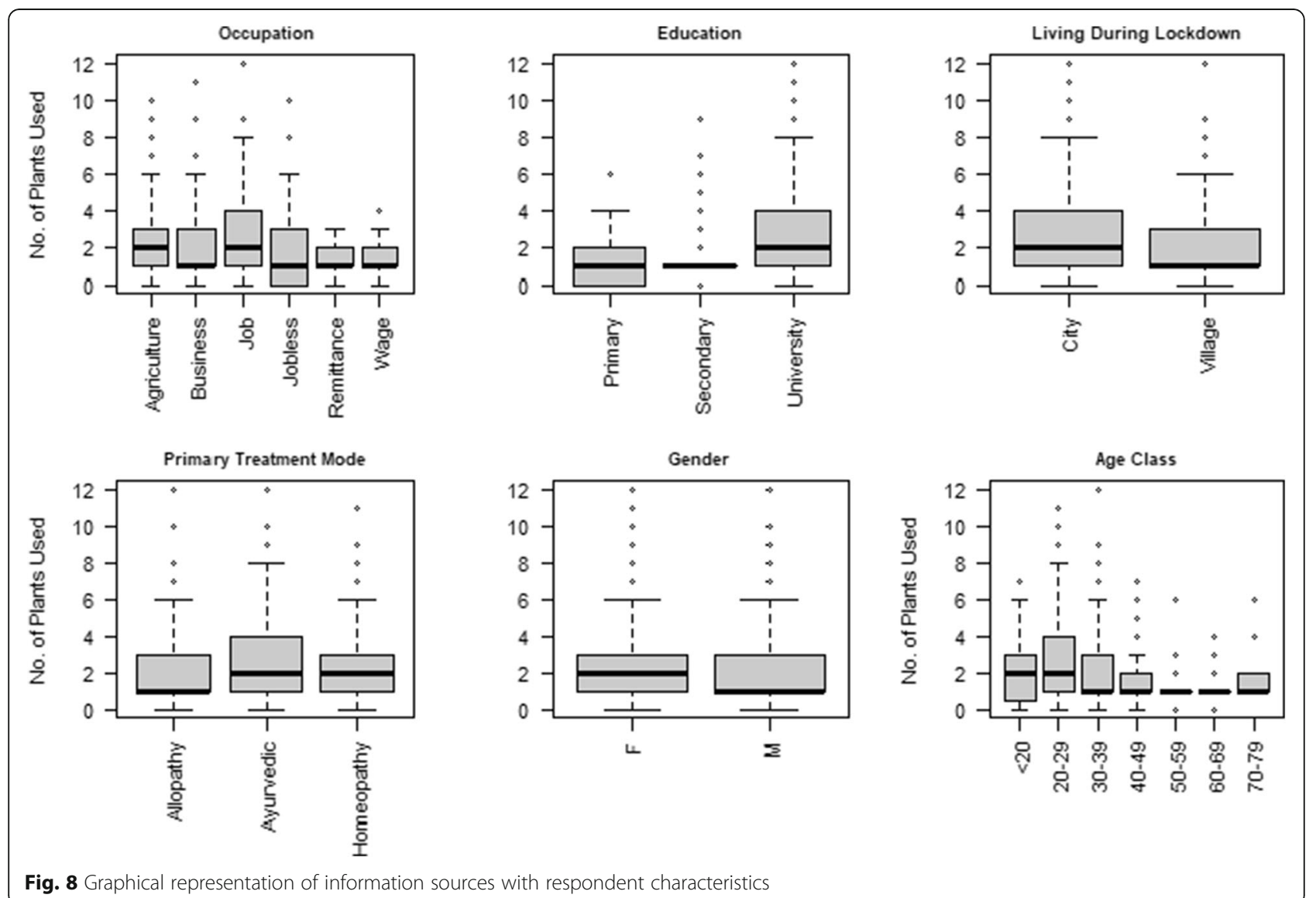


respondents in Nepal reported that the use of medicinal plants has increased during COVID-19 and also believed that information about the medicinal plants has increased, and most of them recommend medicinal plants to prevent COVID-19. Researchers such as Rastogi et al. (2020) and Vellingiri et al. (2020) have claimed that medicinal plant-based treatments should be beneficial to treat and prevent COVID-19 [20, 48]. Yang et al. [49] reported that plant species traditionally used as food can help to enhance the immune system of the body and help to prevent the manifestation of COVID-19 [50]. In the past, medicinal plants were combined with western medicine to treat a similar disease, severe acute respiratory syndrome (SARS) [51].

There is no effective medicine available so far for the treatment of COVID-19; medicinal plants are being used globally that might have increased the demand for medicinal plants [52]. Some plants are useful to treat viral disease, but COVID-19 is a new disease, and the effectiveness of the medicinal plants to cure it has not been tested yet. Therefore, the excessive use of medicinal plants, however, could be problematic and is a matter of concern. Easy access to social media which often publish unreliable advertisements might have a role to play in the increasing use of medicinal plants. Moreover, local availability of medicinal plants and an incorrect belief that medicinal plants have no side effects among people might also be responsible for the same. All the stakeholders including ethnobotanists and community leaders should come together to educate people about the proper use of medicinal plants.

\section{Medicinal plants recorded and frequency of citation}

We recorded a total of 60 plant species, and most of the species were similar to the study based on a preliminary survey in five heavily affected cities, Wuhan, Milan, Madrid, New York, and Rio de Janeiro, and twelve lessaffected rural areas, Appalachia, Jamaica, Bolivia, Romania, Belarus, Lithuania, Poland, Georgia, Turkey, Pakistan, Cambodia, and South Africa, which recorded 193 plant taxa from 69 families [53]. A study in Morocco had recorded a total of 23 species which include some similar species viz. Allium sativum, Allium cepa, and Zingiber officinale [54]. A study from India recorded 15 species [55]. A study from China have screened 26 medicinal plants for possible treatment of COVID-19 [56]; likewise, other studies from China have discussed about medicinal plants similar to our study [57]. A study from Bangladesh screened 149 plants from 71 families and found they have potential molecules for preparing a drug for the treatment of COVID-19 [58].

Most of the species reported in this study are locally available, home garden species, and used for daily food at home. The leaves were the most used parts of the plants corroborating the findings of other related studies in Asia [59,60]. The use of leaves is mainly due to the presence of active secondary metabolites [61]. Underground parts, such as roots and rhizomes, are rich in bioactive constituents [62, 63]. However, indiscriminate use of underground parts might lead to conservation threats particularly to wild species [64]. Similarly, the use of bark in an excessive amount and the whole plant use might create problems in conservatio $\mathrm{n}[65]$.

The citation of species might have been influenced from social media along with the cultural, religious, and community leaders within Nepal and neighboring India. For instance, the famous Hindu Swami Ramdev of India has suggested that Tinospora cordifolia boiled in water, Curcuma angustifolia, Zanthoxylum armatum powder, and Ocimum tenuiflorum leaves can prevent COVID-19 (written in India TV News of 14 March 2020). The most cited species in this study are also the most commonly used species in Nepal, such as Zingiber officinale, $C$. angustifolia, and Allium sativum. These species are planted in almost every household of rural Nepal, and these species are also listed by the Nepal Ministry of Health \& Population Department of Ayurveda \& Alternative Medicine, Teku, Kathmandu, as an alternative medicine to boost the immunity power of people [66]. Plants like Curcuma angustifolia, Cuminum cyminum, Allium sativum, Terminalia bellirica, $Z$. officinale, $O$. tenuiflorum, Cinnamomum species, Piper nigrum, Vitis vinifera, and Citrus spp. were also recommended by the Indian Government to boost immunity power but does not claim to cure or treat COVID-19 [67]. Some of these medicinal plants used might show a placebo effect on people as treatment of diseases like COVID-19 depending on multiple factors such as psychological factor [68].

The medicinal plants reported in the study have different chemical compounds and constituents that have been proved in treating different diseases and ailments. T. bellirica, Cinnamomum species, Piper nigrum, dry Z. officinale, and raisin contain phytonutrients, chlorophyll, vitamins, minerals, eugenol, and a bioactive compound; Z. officinale contains sesquiterpenes [69].

Chemical constituents 8-Gingerol and 10-Gingerol from Z. officinale were active against COVID-19 [70]. COVID-19 patients might have a cytokine storm [71, 72], and Curcuma species like angustifolia and caesia have the capacity to block cytokine release [73]. Allium sativum contains sulfoxide, proteins, and polyphenols like bioactive sulfur-containing compounds which are antiviral with immunostimulatory potential [74, 75]. Tinospora cordifolia has alkaloids, glycosides, lactones, and steroids with immunomodulatory roles and can treat fever, chronic diarrhea, and asthma [76, 77]. Citrus species contain polysaccharides and polyphenolic compounds which improve the immunity of body [78]. 
Ocimum species like Ocimum tenuiflorum extract contains Tulsinol (A, B, C, D, E, F, G) and dihydrodieuginol that possess immunomodulatory and Angiotensinconverting enzyme 2 (ACE II) blocking properties to inhibit replication of coronavirus [79]. Phyllanthus emblica is antioxidative and anti-inflammatory, and its extract Phyllaemblicin G7 has the potential to treat COVID-19 [80]. Azardirachta indica extracts Nimbolin A, Nimocin, and Cycloartanols (24-Methylenecycloartanol and 24Methylenecycloartan-3-one) have shown potential to inhibit COVID-19 [81]. Mentha arvensis possess eugenol, terpenes, and flavonoids which are good antioxidants and modulators of xenobiotic enzymes which help to inhibit COVID-19 [82]. Cinnamom species like Cinnamom unverum contains antioxidant and antiviral compounds (eugenol, cinnamic acid, caryophyllene) which might help to inhibit COVID-19 [83].

The species with a lower frequency of citation are also useful in some way; Camellia sinensis has immunomodulatory properties due to the presence of epigallocatechin gallate, quercetin, and gallic acid in its leaves [84]. Euphorbia species like Euphorbia thymifolia has antioxidant and antiviral activities [85]. Functional food such as Allium cepa, Nigella sativa, Carica papayas, and other species are functional food; they possess immunomodulatory properties in several ways and help in effective health management if taken in an adequate manner [50]. However, there is no proper research and scientific evidence supporting that medicinal plants can prevent or cure COVID-19. The use of medicinal plants is traditional and has a long history with its own theory, like traditional Chinese medicines whose composition is typical and complicated. A creative evaluation system should be developed before its use to prevent or treat COVID-19 [86]. Some researchers have suggested natural products obtained from plants might be an alternative option to treat COVID-19 $[87,88]$.

But at present, the use of different, unproven medicine, as well as herbal medicine, has been the only way to protect vulnerable patients and such medicines should not be overlooked, or taken without the prescription from a health personnel [50]. The effectiveness of abovementioned medicinal plants should be tested scientifically then added to the discovery of drugs used to treat COVID-19.

\section{Source and cultivating conditions of medicinal plants}

Most of the respondents obtained medicinal plants from home gardens or farms. It is interesting to find that people are cultivating more medicinal plants during COVID-19, which is a positive sign for the development of gardening or farming practices in the country. This type of activity will support the sustainable conservation of medicinal plants. However, collecting medicinal plants from the jungle will cause several issues in the conservation of plants [89]. Different types of actions can be taken to conserve and for the sustainable use of such species, including assessing the conditions of plant use and their presence as well as policy formation [90]. Some people have also just started to plant medicinal plants which is a good sign for the sustainable livelihood in Nepal.

\section{Number of plants reported and covariates}

The use of medicinal plants depends on several covariates, such as occupation, education level, age, class, living condition, and treatment methods that people usually follow. The sociocultural acceptance of people vary within different places and communities [91]. People living in villages most live with their families in Nepal, and studies have found that the use of medicinal plants usually comes from families [92]. During COVID19, well-educated people perceived more medicinal plants in Nepal, contrary to the results of other studies, which found that well-educated people often rely on modern medicine for treatment [93]. Females reported more medicinal plants than males, similar to other studies [94], probably because women are more involved in household work and invest more time in the kitchen, caring for their family, and in food and health, as well as in farm work such as cutting grasses and collecting fodder. People adopting agriculture reported a higher number of medicinal plants, which may be because they have easier access to medicinal plants. In Nepal, people with agricultural occupations and living in rural areas used more traditional methods to stay healthy [95]. The job holders also reported comparatively more number of plants.

Interestingly, the youths (age groups below 30) have reported using more medicinal plants, probably because they lived with their families and learned more about the medicinal plants from the elders. This group is also the most active group on social media. Most respondents also claimed that they were more aware of the medicinal plants during COVID-19, which is a good sign as the research by Tiwari et al. (2020) has mentioned that young people are forgetting the use of medicinal plants. However, the misunderstanding of medicinal plants is also dangerous, and the stakeholders need to think about and provide accurate information to the young people [96]. Young people should follow a reliable source to obtain information about medicinal plants. People who primarily use Ayurvedic and homeopathy remedies reported more number of medicinal plants. The use of plants and the acquisition of knowledge usually depends on the culture and primary health care system [97]. 


\section{Information sources and respondent characteristics}

The source of information is the key to using medicinal plants, and it is not good to follow social websites and rely on them, as the usefulness and accuracy of messages regarding COVID-19 provided by social media such as YouTube have not been tested [98]. However, in this study, a large number of respondents were found to be engaged in social media to obtain information regarding COVID-19. Most of the people were not relying on the WHO and national health authorities, similar to the study of Bhagavathula et al. [99]. Most well-educated people, female, job holders, people living with families, people who are following allopathy as a primary treatment, and people who live in the village are all following social media to obtain knowledge of prevention methods and using medicinal plant-based on the source which might be incorrect and thus harmful. This is because the frequent use of social media and the practices of using several sources of social media have caused an overload and increased people's concerns [100].

This study recommends the use of official websites of the $\mathrm{WHO}$ and national health authorities to gain information regarding COVID-19. Most people also rely on the communities for the use of medicinal plants which might cause traditional malfunction. Therefore, it is unwise to adopt unscientific sources of information and use medicinal plants privately. The correct use of medicinal plants passes from generation to generation, which is usually applicable to old diseases. No valid medicine has been developed to prevent or cure COVID-19 so far. The COVID-19 pandemic has created a large crisis, and it needs large-scale behavior changes [101]. For instance, we need to change our behavior and follow valid information to use different preventive measures to be free from COVID-19. The collaboration between diverse stakeholders such as the government, volunteers, people, and other sectors is deemed necessary to transmit information and respond to crisis through improving information flow [102]. Different studies on herbal remedies are deemed necessary which would be helpful to prepare an antiviral drug against COVID-19 as well as to help prevent going against traditional methodology related to the use of medicinal plants [103]. There is an urgent need to disseminate a high level of public awareness to prevent misinformation regarding treatment and prevention measures of COVID-19 [104].

\section{Limitation of the study}

This is online survey based study. The questionnaire was mostly circulated among the educated social network colleagues of ours as they can read and understand about the issues, provide their consent, and fill the form similar to other studies from the globe. This might create some bias on the study, but during extreme condition (such as COVID-19 lockdown) this is one of the prime ways to get information and help deal with the extreme situation. Researchers have reported that well-educated people preferred to follow modern medicine, but during COVID-19 time educated people were aware about the medicinal plants as opportunistic medicine $[105,106]$. This behavior of educated people helps to increase concern of them on medicinal plants. Further, a field-based study might cover responses from all levels and classes of people with quantification of uses.

\section{Conclusion}

This study found that medicinal plants used and the beliefs related to them have increased during COVID-19. A total of 63 medicinal plant species used to prevent COVID-19 were investigated and recorded. The frequently used plants in the home were recorded more in comparison to other plants. The plants' cultivation status have increased during COVID-19. The use of medicinal plants was associated with social and demographic variables. Likewise, the source of medicinal plants also varied with the demographic social factors of the respondents. This study recommends undertaking studies of medicinal plants used during COVID-19. The validity and reliability of such medicinal plants should be tested further by phytochemical and pharmacological research, and invalid information should be monitored and controlled in different social media platforms and communities. It is recommended that people follow information from authentic sources related to the COVID-19 pandemic.

\section{Acknowledgements}

We are highly indebted to all respondents who took part in the survey. We are thankful to Heather Whitefield for editing the English of our manuscript; assistant professor, Department of Botany Trichandra College, Tribhuvan University, Sanu Raja Maharjan for confirming plant names; and the Government of Nepal Ministry of Forest and Environment Department of Plant Resources National Herbarium \& Plant Laboratories (KATH) Godawari, Lalitpur Nepal for deposition of herbarium specimens. We are also thankful to Dr. Shanti Timilsina and Suraj Jha of Aurveda Campus, Tribhuvan University Kirtipur, Bhuwan Parajuli of Nepal Sanskrit University Patanjali Ayurvedic Medical College and Research Center, Chandramani Aryal of Companions for Amphibians and Reptiles of Nepal (CARON), Sandesh

Neupane, Pramananda Rajbanshi, Bishal Sharma, Deepa Karki, and Ankita Chaudhary of GoldenGate International college for helping in herbarium specimen collection and preparation.

\section{Authors' contributions}

DK, MKD, PRM, SS, FFL, and DFC designed the study. DK, MKD, PRM, SB MST, $P C A$, and $A B$ conducted the data collection. DK and PCA analyzed the data. $\mathrm{DK}, \mathrm{MKD}, \mathrm{SS}, \mathrm{DFC}, \mathrm{MST}, \mathrm{SB}, \mathrm{AB}$, and PRM confirmed the plants. DK and SS wrote the manuscript. MKD, PCA, FFL, SB, and DFC reviewed the manuscript. The authors read and approved the final manuscript.

\section{Funding}

This work was supported by the National Key Research and Development Program of China (2017YFC0506200) and the project of National Survey of Traditional Chinese Medicine Resources from National Administration of Traditional Chinese Medicine (GZY-KJS-2018-004). 


\section{Availability of data and materials}

All data have already been included in the manuscript. We are willing to share the data generated and analyzed during the current study.

\section{Declarations}

\section{Ethics approval and consent to participate}

Ethical guidelines of the International Society of Ethnobiology (http://www. ethnobiology.net/) were strictly followed. We wrote a consent message to all the people we reached with the form and placed a clearly written consent message at the top of the form followed by a consent question at the beginning of it.

\section{Consent for publication}

Not applicable.

\section{Competing interests}

The authors declare that they have no competing interests.

\section{Author details}

'Guangdong Key Laboratory for Innovative Development and Utilization of Forest Plant Germplasm, College of Forestry and Landscape Architecture, South China Agricultural University, Guangzhou, China. ${ }^{2}$ Environmental Science Program, Golden Gate International College, Battisputali, Kathmandu, Nepal. ${ }^{3}$ Environment Protection and Study Center (ENPROSC), Baneshwor, Kathmandu, Nepal. ${ }^{4}$ Central Department of Environmental Science, Tribhuvan University, Kirtipur, Kathmandu, Nepal. ${ }^{5}$ State Key Laboratory of Environmental Criteria and Risk Assessment, Chinese Research Academy of Environmental Sciences, Beijing 100012, P.R. China. ${ }^{6}$ Provincial Government Ministry of Social Development, Regional Health Directorate, Dhankuta, Province 1, Nepal. ${ }^{7}$ South China Limestone Plants Research Center, College of Forestry and Landscape Architecture, South China Agricultural University, Guangzhou, China.

\section{Received: 2 October 2020 Accepted: 10 March 2021}

\section{Published online: 08 April 2021}

\section{References}

1. Keni R, Alexander A, Nayak PG, Mudgal J, Nandakumar K. COVID-19: emergence, spread, possible treatments, and global burden. Front Public Health. 2020;8:216. https://doi.org/10.3389/fpubh.2020.00216.

2. Boulware DR, Pullen MF, Bangdiwala AS, Pastick KA, Lofgren SM, Okafor EC, Skipper CP, Nascene AA, Nicol MR, Abassi M, Engen NW. A randomized trial of hydroxychloroquine as postexposure prophylaxis for Covid-19. N Engl J Med. 2020;383(6):517-25.

3. Rome BN, Avorn J. Drug evaluation during the Covid-19 pandemic. N Engl J Med. 2020;382(24):2282-4. https://doi.org/10.1056/NEJMp2009457.

4. Rosa SG, Santos WC. Clinical trials on drug repositioning for COVID-19 treatment. Rev Panam Salud Publica. 2020;44:e40. https://doi.org/10.26633/ RPSP.2020.40.

5. Pennycook G, McPhetres J, Zhang Y, Lu JG, Rand DG. Fighting COVID-19 misinformation on social media: experimental evidence for a scalable accuracy-nudge intervention. Psychol Sci. 2020;31(7):770-8010.1177/ 0956797620939054. https://doi.org/10.1177/0956797620939054.

6. Franco FM, Bussmann RW. Rising to the occasion: outlining ethnobiologists response to the coronavirus (COVID-19) pandemic. Ethnobotany Res Appl. 2020;20:1-4.

7. Van der Veen M. The materiality of plants: plant-people entanglements. World archaeology. 2014;46(5):799-812. https://doi.org/10.1080/00438243.2 014.953710 .

8. Harshberger JW. The purposes of ethno-botany. Botanical gazette. 1896; 21(3):146-54. https://doi.org/10.1086/327316.

9. Martin GJ. Ethnobotany: a methods manual. springer; Kew, United Kingdom: Royal Botanic Gardens; 2014.

10. Harris DR, Hillman G. An evolutionary continuum of people-plant interaction. London: Foraging Farming. Unwin Hyman; 1989;31:11-26.

11. Adnan N, Othman N. The relationship between plants and the Malay culture. Proc Soc Behav Sci. 2012;42:231-41. https://doi.org/10.1016/j. sbspro.2012.04.186.

12. Cunningham AB. Applied ethnobotany: people, wild plant use and conservation. London and Sterling: Earthscan; 2001.
13. Balick MJ, Cox PA. Plants, people, and culture: the science of ethnobotany New York: Scientific American Library. 1996.

14. Fabricant DS, Farnsworth NR. The value of plants used in traditional medicine for drug discovery. Environ Health Perspect. 2001;109(suppl 1):69-75.

15. Arora R, Chawla R, Marwah R, Arora P, Sharma RK, Kaushik V, et al. Potential of complementary and alternative medicine in preventive management of Novel H1N1 Flu (Swine Flu) pandemic: thwarting potential disasters in the bud. Evid Based Complement Alternat Med. 2011;2011:586506. https://doi. org/10.1155/2011/586506.

16. Mukhtar M, Arshad M, Ahmad M, Pomerantz RJ, Wigdahl B, Parveen Z. Antiviral potentials of medicinal plants. Virus Res. 2008;131(2):111-2010. 1016/j.virusres.2007.09.008.

17. Kisangau DP, Herrmann TM, Lyaruu HV, Hosea KM, Joseph CC, Mbwambo $\mathrm{ZH}$, et al. Traditional knowledge, use practices and conservation of medicinal plants for HIV/AIDS care in rural Tanzania. 2011.

18. Luo H, Tang QL, Shang YX, Liang SB, Yang M, Robinson N, et al. Can Chinese medicine be used for prevention of corona virus disease 2019 (COVID-19)? A review of historical classics, research evidence and current prevention Programs. Chin J Integr Med. 2020;26(4):243-5010.1007/s11655-020-3192-6.

19. Chan KW, Wong VT, Tang SCW. COVID-19: an update on the epidemiological, clinical, preventive and therapeutic evidence and guidelines of integrative Chinese-Western medicine for the management of 2019 novel coronavirus disease. Am J Chin Med. 2020;48(3):737-6210.1142/ S0192415X20500378.

20. Vellingiri B, Jayaramayya K, lyer M, Narayanasamy A, Govindasamy V, Giridharan B, et al. COVID-19: a promising cure for the global panic. Sci Total Environ. 2020;725:138277. https://doi.org/10.1016/j.scitotenv.2020.138277.

21. Shankar A, Dubey A, Saini D, Prasad CP. Role of complementary and alternative medicine in prevention and treatment of COVID-19: an overhyped hope. Chin J Integr Med. 2020;26(8):565-7. https://doi.org/10.1 007/s11655-020-2851-y.

22. Ni L, Zhou L, Zhou M, Zhao J, Wang DW. Combination of Western medicine and Chinese traditional patent medicine in treating a family case of COVID19. Front Med. 2020;14(2):210-4. https://doi.org/10.1007/s11684-020-0757-x.

23. Luo L, Jiang J, Wang C, Fitzgerald M, Hu W, Zhou Y, et al. Analysis on herbal medicines utilized for treatment of COVID-19. Acta Pharm Sin B. 2020;10(7): 1192-204. https://doi.org/10.1016/j.apsb.2020.05.007.

24. Gasmi A, Noor S, Tippairote T, Dadar M, Menzel A, Bjorklund G. Individual risk management strategy and potential therapeutic options for the COVID19 pandemic. Clin Immunol. 2020;215:108409. https://doi.org/10.1016/j. clim.2020.108409.

25. Chan AKM, Nickson CP, Rudolph JW, Lee A, Joynt GM. Social media for rapid knowledge dissemination: early experience from the COVID-19 pandemic. Anaesthesia:2020. https://doi.org/10.1111/anae.15057.

26. Pandey A, Patni N, Singh M, Sood A, Singh G. YouTube as a source of information on the H1N1 influenza pandemic. Am J Prev Med. 2010;38(3): e1-3. https://doi.org/10.1016/j.amepre.2009.11.007.

27. Utari WR, Lisum K, Marlina PWN. Relationship of respondent characteristics and information sources with knowledge anemia deficiency of iron in adolescents. Jurnal Keperawatan. 2020;12(3):379-86.

28. Gewali MB, Awale S. Aspects of traditional medicine in Nepal. Japan: Institute of Natural Medicine University of Toyama; 2008.

29. Banerji ML. Some edible and medicinal plants from East Nepal. J Bombay Natl Hist Soc. 1955;53:153-5.

30. Manandhar NP. Plants and people of Nepal. Timber press; 2002. https:// books.google.com.np/books?id=kIAFeYz4YdYC.

31. Adhikari M, Thapa R, Kunwar RM, Devkota HP, Poudel P. Ethnomedicinal uses of plant resources in the Machhapuchchhre Rural Municipality of Kaski District, Nepal. Medicines (Basel). 2019;6(2). https://doi.org/10.3390/ medicines6020069.

32. Budha-Magar S, Bhandari P, Ghimire SK. Ethno-medicinal survey of plants used by Magar (Kham) community, Rolpa district, Western Nepal. Ethnobotany Res Appl. 2020;19:1-29.

33. Bhattarai N. Folk herbal remedies for diarrhoea and dysentery in central Nepal. FITOTERAPIA-MILANO-. 1993;64:243.

34. Kunwar RM, Bussmann RW. Ethnobotany in the Nepal Himalaya. J Ethnobiol Ethnomed. 2008;4(1):24. https://doi.org/10.1186/1746-4269-4-24.

35. Timmermann L, Smith-Hall C. Commercial medicinal plant collection is transforming high-altitude livelihoods in the Himalayas. Mt Res Dev. 2019; 39(3):R13-21. https://doi.org/10.1659/MRD-JOURNAL-D-18-00103.1. 
36. Ghimire SK, Awasthi B, Rana S, Rana HK, Bhattarai R, Pyakurel D. Export of medicinal and aromatic plant materials from Nepal. Botanica Orientalis. 2016;10:24-32. https://doi.org/10.3126/botor.v10i0.21020.

37. Ambu G, Chaudhary RP, Mariotti M, Cornara L. Traditional uses of medicinal plants by ethnic people in the Kavrepalanchok district, Central Nepal. Plants. 2020;9(6):759.

38. Chalise HN. COVID-19 situation and challenges for Nepal. Asia Pac J Public Health. 2020;32(5):281-2. https://doi.org/10.1177/1010539520932709.

39. Pandit RD, Singh RK. COVID-19 Ayurveda treatment protocol of governments of Nepal and India: a review and perspective. Appl Sci Technol Ann. 2020;1(1):72-80. https://doi.org/10.3126/asta.v1i1.30276.

40. International Society of Ethnobiology (2006). International Society of Ethnobiology Code of Ethics (with 2008 additions) http://ethnobiology.net/ code-of-ethics/.

41. Shrestha K. Dictionary of Nepalese plant names: Mandala Book Point Kantipath, Kathmandu, Nepal; 1998.

42. Kunwar RM, Shrestha KP, Bussmann RW. Traditional herbal medicine in farwest Nepal: a pharmacological appraisal. J Ethnobiol Ethnomed. 2010;6:35. https://doi.org/10.1186/1746-4269-6-35.

43. Singh M, Malla S, Rajbhandari S, Manandhar A. Medicinal plants of Nepal-retrospects and prospects. Econ Bot. 1979;33(2):185-98. https://doi. org/10.1007/BF02858287.

44. Tardío J, Pardo-de-Santayana M. Cultural importance indices: a comparative analysis based on the useful wild plants of Southern Cantabria (Northern Spain). Econ Bot. 2008:62(1):24-39. https://doi.org/10.1007/s12231-007-9004-5.

45. RCore T. R: a language and environment for statistical computing. Vienna: R Foundation for Statistical Computing; 2016.

46. Tahir UI Qamar M, Alqahtani SM, Alamri MA, Chen LL. Structural basis of SARS-CoV-2 3CL(pro) and anti-COVID-19 drug discovery from medicinal plants. J Pharm Anal. 2020;10(4):313-9. https://doi.org/10.1016/j.jpha.2020.03. 009.

47. Zohra T, Ovais M, Khalil AT, Qasim M, Ayaz M, Shinwari ZK, et al. Bio-guided profiling and HPLC-DAD finger printing of Atriplex lasiantha Boiss. BMC Complement Altern Med. 2019;19(1):4. https://doi.org/10.1186/s12906-0 8-2416-1.

48. Rastogi S, Pandey DN, Singh RH. COVID-19 pandemic: a pragmatic plan for ayurveda intervention. J Ayurveda Integr Med. 2020. https://doi.org/10.1016/ j.jaim.2020.04.002.

49. Yang F, Zhang Y, Tariq A, Jiang X, Ahmed Z, Zhihao Z, Idrees M, Azizullah A, Adnan M, Bussmann RW. Food as medicine: A possible preventive measure against coronavirus disease (COVID-19). Phytother Res. 2020;34(12):3124-36.

50. Fan $Y$, Zhang $Y$, Tariq A, Jiang $X$, Ahamd Z, Zhihao Z, et al. Food as medicine: a possible preventive measure against coronavirus disease (COVID-19). Phytother Res. 2020.

51. Liu X, Zhang M, He L, Li Y. Chinese herbs combined with Western medicine for severe acute respiratory syndrome (SARS). Cochrane Database Syst Rev. 2012;10:CD004882. https://doi.org/10.1002/14651858.CD004882.pub3.

52. Vandebroek I, Pieroni A, Stepp JR, Hanazaki N, Ladio A, Alves RRN, et al. Reshaping the future of ethnobiology research after the COVID-19 pandemic. Nat Plants. 2020;6(7):723-30. https://doi.org/10.1038/s41477-0200691-6.

53. Pieroni A, Vandebroek I, Prakofjewa J, et al. Taming the pandemic? The importance of homemade plant-based foods and beverages as community responses to COVID-19. J Ethnobiol Ethnomed. 2020;16:75. https://doi.org/1 0.1186/s13002-020-00426-9.

54. EL Alami A, Fattah A, Chait A. Medicinal plants used for the prevention purposes during the covid-19 pandemic in Morocco. J Anal Sci Appl Biotechnol. 2020;2(1):4-11.

55. Srivastava A, Chaurasia J, Khan R, Dhand C, Verma S. Role of medicinal plants of traditional use in recuperating devastating COVID-19 situation. Med Aromat Plants (Los Angeles). 2020;9(359):2167-0412.

56. Xu J, Zhang Y. Traditional Chinese medicine treatment of COVID-19. Complement Ther Clin Pract. 2020;39:101165. https://doi.org/10.1016/j.ctcp.2 020.101165 .

57. Shahrajabian MH, Sun W, Shen $\mathrm{H}$, Cheng Q. Chinese herbal medicine for SARS and SARS-CoV-2 treatment and prevention, encouraging using herbal medicine for COVID-19 outbreak. Acta Agric Scand Sect B-Soil Plant Sci. 2020;70(5):437-43.

58. Bhuiyan FR, Howlader S, Raihan T, Hasan M. Plants metabolites: possibility of natural therapeutics against the COVID-19 pandemic. Front Med (Lausanne). 2020;7:444. https://doi.org/10.3389/fmed.2020.00444.
59. Ahmad KS, Hamid A, Nawaz F, Hameed M, Ahmad F, Deng J, et al. Ethnopharmacological studies of indigenous plants in Kel village, Neelum Valley, Azad Kashmir, Pakistan. J Ethnobiol Ethnomed. 2017;13(1):68. https:// doi.org/10.1186/s13002-017-0196-1.

60. Amjad MS, Qaeem MF, Ahmad I, Khan SU, Chaudhari SK, Zahid Malik N, et al. Descriptive study of plant resources in the context of the ethnomedicinal relevance of indigenous flora: a case study from Toli Peer National Park, Azad Jammu and Kashmir, Pakistan. Plos One. 2017;12(2): e0171896. https://doi.org/10.1371/journal.pone.0171896.

61. Ghorbani A. Studies on pharmaceutical ethnobotany in the region of Turkmen Sahra, north of Iran: (Part 1): General results. J Ethnopharmacol. 2005;102(1):58-68. https://doi.org/10.1016/j.jep.2005.05.035.

62. Noctor $\mathrm{G}$, Foyer $\mathrm{CH}$. Ascorbate and glutathione: keeping active oxygen under control. Annu Rev Plant Physiol Plant Mol Biol. 1998;49:249-79. https://doi.org/10.1146/annurev.arplant.49.1.249.

63. Basualdo I, Zardini E, Ortiz M. Medicinal plants of Paraguay: underground organs. Econ Bot. 1991;45(1):86-96. https://doi.org/10.1007/BF02860052.

64. Hussain A, Abbasi M, Hussain N, Majid S. A survey of important indigenous medicinal plants of district Bhimber Azad Jammu \& Kashmir, Pakistan. Int J Adv Res. 2013;1:635-44.

65. Faroog A, Amjad MS, Ahmad K, Altaf M, Umair M, Abbasi AM. Ethnomedicinal knowledge of the rural communities of Dhirkot, Azad Jammu and Kashmir, Pakistan. J Ethnobiol Ethnomed. 2019;15(1):45. https:// doi.org/10.1186/s13002-019-0323-2.

66. Ayurveda and Alternative Medicine Guidelines of Preventive Measures and Management Protocol for COVID 19 in Nepal. In: Department of Ayurveda \& Alternative Medicine MoHP, Nardevi NAMC, Ayurveda Campus \& Teaching Hospital K, editors. Kathmandu, Nepal 2020.

67. Rajkumar RP. Ayurveda and COVID-19: where psychoneuroimmunology and the meaning response meet. Brain Beha Immun. 2020;87:8-9. https://doi. org/10.1016/j.bbi.2020.04.056

68. Batty G, Deary I, Luciano M, Altschul D, Kivimäki M, Gale C. Psychosocial factors and hospitalisations for COVID-19: prospective cohort study based on a community sample. Brain Behav Immun. 2020;89:569-78. https://doi. org/10.1016/j.bbi.2020.06.021

69. Prajapati S, Kumar N. SARS-CoV-2 pandemic: an opportunity for Indian traditional medicines (AYUSH). Int J Complement Alt Med. 2020;13(3):103-5.

70. Rajagopal K, Byran G, Jupudi S, Vadivelan R. Activity of phytochemical constituents of black pepper, ginger, and garlic against coronavirus (COVID19): an in silico approach. Int J Health Allied Sci. 2020;9(5):43.

71. Bhaskar S, Sinha A, Banach M, Mittoo S, Weissert R, Kass JS, et al. Cytokine storm in COVID-19-immunopathological mechanisms, clinical considerations, and therapeutic approaches: the REPROGRAM Consortium Position Paper. Front Immunol. 2020;11:1648. https://doi.org/10.3389/ fimmu.2020.01648.

72. Mehta P, McAuley DF, Brown M, Sanchez E, Tattersall RS, Manson JJ, et al. COVID19: consider cytokine storm syndromes and immunosuppression. Lancet. 2020; 395(10229):1033-4. https://doi.org/10.1016/S0140-6736(20)30628-0.

73. Sordillo PP, Helson L. Curcumin suppression of cytokine release and cytokine storm. A potential therapy for patients with Ebola and other severe viral infections. In Vivo. 2015;29(1):1-4

74. Anywar G, Kakudidi E, Byamukama R, Mukonzo J, Schubert A, Oryem-Origa $H$. Medicinal plants used by traditional medicine practitioners to boost the immune system in people living with HIV/AIDS in Uganda. Eur J Integr Med. 2020:35:101011. https://doi.org/10.1016/j.eujim.2019.101011.

75. Sahoo B, Banik B. Medicinal plants: source for immunosuppressive agents. Immunol Curr Res. 2018;2(106):2.

76. Saha S, Ghosh S. Tinospora cordifolia: One plant, many roles. Anc Sci Life. 2012;31(4):151-910.4103/0257-7941.107344-9. https://doi.org/10.4103/02577941.107344.

77. Parthipan M, Aravindhan V, Rajendran A. Medico-botanical study of Yercaud hills in the eastern Ghats of Tamil Nadu, India. Anc Sci Life. 2011;30(4):104-9.

78. Shen C-Y, Jiang J-G, Li M-Q, Zheng C-Y, Zhu W. Structural characterization and immunomodulatory activity of novel polysaccharides from Citrus aurantium Linn. variant amara Engl. J Funct Foods. 2017;35:352-62. https:// doi.org/10.1016/j.jf.2017.05.055.

79. Varshney KK, Varshney M, Nath BMolecular Modeling of isolated phytochemicals from Ocimum sanctum towards exploring potential inhibitors of SARS coronavirus main protease and papain-like protease to treat COVID-19. Available at SSRN 3554371. 2020 
80. Wu C, Liu Y, Yang Y, Zhang P, Zhong W, Wang Y, et al. Analysis of therapeutic targets for SARS-CoV-2 and discovery of potential drugs by computational methods. Acta Pharm Sin B. 2020;10(5):766-88. https://doi. org/10.1016/j.apsb.2020.02.008.

81. Borkotoky S, Banerjee M. A computational prediction of SARS-CoV-2 structural protein inhibitors from Azadirachta indica (Neem). J Biomol Struct Dyn. 2020:1-17. https://doi.org/10.1080/07391102.2020.1774419.

82. Kong AN, Yu R, Chen C, Mandlekar S, Primiano T. Signal transduction events elicited by natural products: role of MAPK and caspase pathways in homeostatic response and induction of apoptosis. Arch Pharm Res. 2000; 23(1):1-16. https://doi.org/10.1007/BF02976458.

83. Singh N, Rao AS, Nandal A, Kumar S, Yadav SS, Ganaie SA, et al. Phytochemical and pharmacological review of Cinnamomum verum $\mathrm{J}$. Presl-a versatile spice used in food and nutrition. Food Chem. 2020;338: 127773. https://doi.org/10.1016/j.foodchem.2020.127773.

84. Kumar D, Arya V, Kaur R, Bhat ZA, Gupta VK, Kumar V. A review of immunomodulators in the Indian traditional health care system. J Microbiol Immunol Infect. 2012;45(3):165-84. https://doi.org/10.1016/j.jmii.2011.09.030.

85. Lin CC, Cheng HY, Yang CM, Lin TC. Antioxidant and antiviral activities of Euphorbia thymifolia L. J Biomed Sci. 2002;9(6 Pt 2):656-64. https://doi.org/1 $0.1159 / 000067281$

86. Li T, Lu H, Zhang W. Clinical observation and management of COVID-19 patients. Emerg Microbes Infect. 2020;9(1):687-90. https://doi.org/10.1 080/22221751.2020.1741327.

87. Shinwari ZK, Qaiser M, Nasar MQ, Ali A. Indigenous knowledge based herbal medicine for corona (COVID-19) treatment. Pak J Bot. 2020;52(4):1427-34.

88. Benarba B, Pandiella A. Medicinal plants as sources of active molecules against COVID-19. Front Pharmacol. 2020;11. https://doi.org/10.3389/fphar.2 020.01189 .

89. Kramer AT, Havens K. Plant conservation genetics in a changing world. Trends Plant Sci. 2009;14(11):599-607. https://doi.org/10.1016/j.tplants.2009. 08.005 .

90. Hamilton AC. Medicinal plants, conservation and livelihoods. Biodivers Conserv. 2004;13(8):1477-517. https://doi.org/10.1023/B:BIOC. 0000021333.23413 .42 .

91. Teka A, Asfaw Z, Demissew S, Van Damme P. Medicinal plant use practice in four ethnic communities (Gurage, Mareqo, Qebena, and Silti), south central Ethiopia. J Ethnobiol Ethnomed. 2020;16:1-12.

92. De Sousa JA, Silva YS, Roque F, da Costa Fernandes SD, Delgado MN. Use of medicinal plants and socioeconomic evaluation of urban and rural populations of Sobradinho (DF-Brazil). Rev Agrogeoambiental. 2020; 12(1):50-63. https://doi.org/10.18406/2316-1817v12n120201416.

93. Jan HA, Jan S, Bussmann RW, Ahmad L, Wali S, Ahmad N. Ethnomedicinal survey of the plants used for gynecological disorders by the indigenous community of District Buner, Pakistan. Ethnobot Res Appl. 2020 ;19:1-18. https://doi.org/10.32859/era.

94. Hu R, Lin C, Xu W, Liu Y, Long C. Ethnobotanical study on medicinal plants used by Mulam people in Guangxi, China. J Ethnobiol Ethnomed. 2020; 16(1):1-50.

95. Rajbanshi N, Thapa LB. Traditional knowledge and practices on utilizing medicinal plants by endangered Kisan ethnic group of eastern Nepal. Ethnobot Res Appl. 2019;18:1-9.

96. Tiwari D, Sah AN, Bawari S, Bussmann RW. Ethnobotanical investigations on plants used in folk medicine by native people of Kumaun Himalayan Region of India. Ethnobot Res Appl. 2020;20:1-35.

97. Kunwar RM, Fadiman M, Thapa S, Acharya RP, Cameron M, Bussmann RW. Plant use values and phytosociological indicators: implications for conservation in the Kailash Sacred Landscape, Nepal. Ecol Indicators. 2020; 108:105679. https://doi.org/10.1016/j.ecolind.2019.105679.

98. Li HO-Y, Bailey A, Huynh D, Chan J. YouTube as a source of information on COVID-19: a pandemic of misinformation? BMJ Global Health. 2020:5(5): e002604. https://doi.org/10.1136/bmjgh-2020-002604

99. Bhagavathula AS, Aldhaleei WA, Rahmani J, Mahabadi MA, Bandari DK. Novel coronavirus (COVID-19) knowledge and perceptions: a survey on healthcare workers. MedRxiv. 2020. https://doi.org/10.1101/2020.03.09.2 0033381.

100. Farooq A, Laato S, Islam A. Impact of online information on self-isolation intention during the COVID-19 pandemic: cross-sectional study. J Med Internet Res. 2020;22(5):e19128. https://doi.org/10.2196/19128.

101. Van Bavel JJ, Baicker K, Boggio PS, Capraro V, Cichocka A, Cikara M, Crockett MJ, Crum AJ, Douglas KM, Druckman JN, Drury J. Using social and behavioural science to support COVID-19 pandemic response. Nat Hum Behav. 2020;4(5):460-71.

102. Pan SL, Cui M, Qian J. Information resource orchestration during the COVID19 pandemic: a study of community lockdowns in China. Int J Inf Manage. 2020;54:102143. https://doi.org/10.1016/j.ijinfomgt.2020.102143.

103. Mirzaie A, Halaji M, Dehkordi FS, Ranjbar R, Noorbazargan H. A narrative literature review on traditional medicine options for treatment of corona virus disease 2019 (COVID-19). Complement Ther Clin Pract. 2020;40:101214. https://doi.org/10.1016/j.ctcp.2020.101214

104. Sugavanam SC, Natarajan B. Pseudoscientific beliefs and practices in the COVID-19 pandemic: a narrative review of unwanted experiments attributed to social media-based misinformation afflicting the public health. J Health Biol Sci. 2020;8(1):1-9. https://doi.org/10.12662/2317-3076jhbs.v8i1.3394.p19.2020 .

105. Tewelde F, Mesfin M, Tsewene S. Ethnobotanical survey of traditional medicinal practices in LaelayAdi-Yabo District, Northern Ethiopia. Int J Ophthalmol Visual Sci. 2017;2(4):80-7.

106. Hong L, Guo Z, Huang K, Wei S, Liu B, Meng S, et al. Ethnobotanical study on medicinal plants used by Maonan people in China. J Ethnobiol Ethnomed. 2015;11(1):32. https://doi.org/10.1186/s13002-015-0019-1.

\section{Publisher's Note}

Springer Nature remains neutral with regard to jurisdictional claims in published maps and institutional affiliations.
Ready to submit your research? Choose BMC and benefit from:

- fast, convenient online submission

- thorough peer review by experienced researchers in your field

- rapid publication on acceptance

- support for research data, including large and complex data types

- gold Open Access which fosters wider collaboration and increased citations

- maximum visibility for your research: over $100 \mathrm{M}$ website views per year

At $\mathrm{BMC}$, research is always in progress.

Learn more biomedcentral.com/submissions 